Received, February 2020

Revised, September 2020

Accepted, July 2021

https://ejournal.unperba.ac.id/index.php/pijeb

\title{
THE EFFECT OF JOB MONITORING AND ORGANIZATIONAL COMMUNICATION ON EMPLOYEE'S JOB EFFECTIVENESS
}

\author{
Wike Pertiwi ${ }^{1}$, Eka Pariyanti $^{2 *}$, Rachmaniar Myrianda Dwiputri $^{3}$ \\ ${ }^{1}$ Universitas Buana Perjuangan Karawang, Indonesia \\ ${ }^{2 *}$ Sekolah Tinggi Ilmu Ekonomi ( STIE ) Lampung Timur, Indonesia \\ ${ }^{3}$ Universitas Krisnadwipayana, Indonesia \\ ${ }^{1}$ Email: wike.pertiwi@ubpkarawang.ac.id \\ 2* Email: ekaparianti10@gmail.com \\ ${ }^{3}$ Email: rachmaniarmd@unkris.ac.id
}

\begin{abstract}
This study aimed to examine the effect of job monitoring and organizational communication on employee's job effectiveness. The author utilized a descriptive study method and a verification method. The study population was all employees of BPJS KC Kuningan amounted to 30 people. The sample amount determination was conducted using a saturated sample. The number of samples taken in the study follows the population, i.e., 30 respondents. The study result shows that a hypothesis stating that job monitoring partially and significantly affects employee's job effectiveness was supported. The second hypothesis was also supported, where a positive and significant effect is present between organizational communication and job effectiveness.
\end{abstract}

Keywords: Monitoring, Organizational communication, Employee's job effectiveness

\section{Background}

Human resource is crucial, particularly for an organization or company, either engaging in a production line or service field. Each government or private organization is required to work effectively and efficiently. Employee's job effectiveness is one of the vital factors in organization activities requiring assistance and development to effectively achieve organizational objectives. A job is declared effective when all goals are achieved timely using specific sources allocated to conduct the said activities. Employee's job effectiveness can be determined by comparing the assigned job period with the time required by employees and by comparing between the achieved results or outcomes with the assigned quality. If the outcome is better than what is expected, the employee is categorized as effective.
Several factors may affect an employee's job effectiveness, e.g., leadership style, monitoring, job competency, and organizational communication (Sirait, 2014). It is in line with Steers (2015), asserting several factors affecting job effectiveness, i.e., organization characteristics, environment characteristics, communication process, achievement environment, leadership and decision-making, and different employee characteristics. These are strong reasons for the monitoring importance (Rido \& Nongkeng, 2019).

Many factors influence employee's job effectiveness; however, the author focused on monitoring and organizational communication. It is essential to implement monitoring of organizational activity continuity. The monitoring function is the final function of the management process. An effective monitoring system should 
follow several monitoring principles, i.e., the presence of specific plans and instructions and authorities to subordinates. A plan is the standard or measure of works completed by subordinates. Furthermore, employee's job effectiveness is also influenced by organizational communication, including the communication from superiors to subordinates, communication from subordinates to superiors, and communication among coworkers.

Although many argue that both antecedents are significantly affecting employee's job effectiveness (Rahayu, 2006; Rido \& Nongkeng, 2019; Subekhan, 2017), a study concluded the correlation between monitoring and employee's job effectiveness in the District Office of North Samarinda, Samarinda City, where the relationship level of both variables in correlation coefficient interpretation was categorized as sufficient. Due to this difference, a study is required to be carried out in the BJPS KC Kuningan Office because, to date, studies mainly focused on the Regency Secretariate (Ilyas, \& Saputro, 2020), Population Control and Family Planning Office (Rido, \& Nongkeng, 2019), Unit Sekip Medan Unit (Devi, 2016), and District (Sudrajat, 2020). Studies on BPJS offices are limited, especially in BPJS KC Kuningan,

\section{Literature Review and Hypothesis Development}

\section{The Effect of Monitoring on} Employee's Job Effectiveness

Kumorotomo (1991) points that monitoring is implemented to create an orderly administration system, prevent state money leakage, and guarantee effectiveness and efficiency. Monitoring is an observation process of all organization activities to ensure that all works follow the predetermined plan (Noor, 2013). Stoner argues that monitoring is a process to ensure that all conducted activities follow the plan. Siagian (2003) states that monitoring is an observation process of all organization activities to ensure that all works follow the predetermined plan.
Meanwhile, effectiveness (Sedarmayanti, 2009) is defined as a measure of illustration concerning the extent of the organization performing its job according to the predetermined plan, goal, and objective. Each organization should plan objectives and goals appropriately to achieve the expected result, which can be declared as having high effectiveness. Jon effectiveness (Siagian, 2015) means finishing the job promptly. The decision of whether a task is considered good or bad depends on when the job is finished and does not answer the question of how it is done and how much the cost is. From the above opinion, it can be concluded that, indeed, job effectiveness is primarily a person or several people, particularly employees of an organization or company unit, achieving objectives in a system determined by a notion to fulfill the system need.

Monitoring is not limited to a specific activity or function but is applied to all activities with big roles in the company continuity. Continuous monitoring enables an organization to foresee possible obstacles and anticipate them before they become major problems hindering organization continuity and employee's job effectiveness. Regarding monitoring employee's job effectiveness, monitoring has positive values (Bakhri, Nanik,, \& Pariyanti, 2021), e.g., increase job productivity. Also, various studies agree that monitoring affects employee's job effectiveness (Melani, \& Haryono, 2016; Rahayu, 2006; Rido, \& Nongkeng, 2019; Subekhan, 2017). From these study results, the author hypothesizes:

H1: Monitoring positively and significantly affects employee's job effectiveness

\section{The Effect of Organizational communication on Employee's Job Effectiveness}

Katz and Kahn (1978) assert that organizational communication is information flow, information exchange, and transference of meaning in an organization. Meanwhile, Greebaunm (2004) explains that organizational communication is categorized 
into formal and informal information flows in an organization. According to Monge and Russel (2006), organizational communication is the process of collecting, processing, storing, and distributing communication, enabling the organization to function. Pace and Faules (2006) argue that organizational communication is a message display and interpretation between communication units that are a part of a particular organization. It is then concluded that organizational communication occurs in an organization where message exchange depends on the organization network to achieve meaning similarity.

Communication within an organization should be observed from various sides, i.e., communication between superiors and subordinates, communication among employees, and communication between subordinates and superiors. Relationship maintenance can be constructed from communication between leaders and employees and among employees to maintain cooperation to maximize organization performance. Effective communication is considered the leading key to success, associated with attempts of change. Communication plays a vital role in employee's job effectiveness. If an order or policy is poorly communicated, negative impacts will follow on employee's job effectiveness. Wilson (2012) states that communication is a crucial tool to deliver or receive information to or from other parties. Precedent studies have revealed that organizational communication affects employee's job effectiveness (Ichsan, 2019; Kusuma, \& Amah, 2017; Mokodompit, 2013; Rustiana \& Rosmawati, 2010; Simamora, 2018). Therefore, in this study, the hypothesis is:

$\mathrm{H} 2$ : Organizational communication positively and significantly affects

Method employee's job effectiveness

\section{a. Population}

A population is a generalization area consisting of objects or subjects with quantity and characteristics determined by the author to be examined and concluded. Thus, the population is not limited to people but includes all characteristics of the associated object or subject (Sugiyono, 2016). The study population was all employees of BPJS KC Kuningan Office amounted to 30 people.

\section{b. Sample}

A sample is a part of characteristics obtained by a population, and it should be representing (Sugiyono,2016). The determination of sample number in the current study was performed using saturated sampling. According to Sugiyono (2016), saturated sampling is a sampling technique where all population members are considered samples. Therefore, the number of samples in this study equals the population, i.e., 30 respondents.

\section{c. Data collection technique}

Collecting data in this study by observation, interviews and questionnaires. The questionnaire was distributed to 30 employees working in the BPJS KC Kuningan office. The number of questionnaires distributed, returned in the same number.

\section{d. Measurement and Data Scale}

In this study, the measurement scale utilized to measure study variables was the Likert scale. Sugiyono (2016) states that the Likert scale is used to measure the attitude, opinion, and perception of a person or people regarding social phenomena. Likert scale enables gradation of respondent answers from each question item from very positive to very negative.

\section{e. Data Analysis Technique}

Before performing the data analysis test, validity and reliability tests were performed. Then, the analysis technique employed in the current study was a simple linear regression model. Simple linear regression was utilized to discover the effect of job monitoring and organizational communication on employee's job effectiveness. In general, the fundamental formula or simple linear regression is:

$$
\mathrm{Y}=\mathrm{a}+\mathrm{bx}
$$




\section{Result and Discussion}

\section{A. Result}

The validity test result shows a number over $r$ table of 0.361 for all question items. It indicates that all question items are reliable and eligible to be used in the study. The reliability test result of all question items was over 0.6 , meaning that each variable in this study was reliable. All respondents were consistent in answering each question item measuring each variable.

Table 1. Regression analysis result

\begin{tabular}{lccc}
\hline \multicolumn{1}{c}{ Steps } & $\boldsymbol{\beta}$ & $\mathbf{t}$ & Sig. \\
\hline $\begin{array}{l}\text { Monitoring on job } \\
\text { effectiveness }\end{array}$ & 0.651 & 2.234 & 0.008 \\
$\begin{array}{l}\text { Communication on } \\
\text { job effectiveness }\end{array}$ & 0.754 & 2.357 & 0.004 \\
\hline
\end{tabular}

Table analysis:

a. Regression coefficient value of job monitoring variable $(\mathrm{b2})=\mathbf{0 , 6 5 1}$

The regression coefficient value of job monitoring variable was positive by 0.651 , assuming that other independent variables were fixed. It shows that job monitoring could increase employee's job effectiveness by $1 \%$ or $65.1 \%$.

Furthermore, the $t$ calculation result of job monitoring variable was $\mathbf{2 , 2 3 4} \geq \mathrm{t}$ table value by $\mathbf{2 , 0 5 9}$, with sig value of $0,008 \leq$ sig value of 0,05 . Thus, job monitoring significantly affects job effectiveness. It is concluded that job monitoring $\left(\mathrm{X}_{2}\right)$ positively and significantly affects job effectiveness. Hypothesis H1 was true or supported.

b. Regression coefficient value of organizational communication variable (b4) $=\mathbf{0 , 7 5 4}$

The regression coefficient value of organizational communication variable was positive by 0.754 , assuming that other independent variables were fixed. It shows that organizational communication could increase employee's job effectiveness by $1 \%$ or $75.4 \%$.

Furthermore, the $\mathrm{t}$ calculation result of organizational communication variable was $\mathbf{2 , 3 5 7} \geq \mathrm{t}$ table value by $\mathbf{2 , 0 5 9}$, with sig value of $0,004 \leq \operatorname{sig}$ value of 0,05 . Thus, organizational communication significantly affects job effectiveness. It is concluded that organizational communication $\left(\mathrm{X}_{4}\right)$ positively and significantly affects job effectiveness. Hypothesis $\mathbf{H} 2$ was true or supported.

\section{B. Discussion}

From the hypothesis $\mathrm{H} 1$ testing result, job monitoring positively and significantly affected the job effectiveness of BPJS KC Kuningan Office employees. Another factor influencing job effectiveness is monitoring. Monitoring is crucial in an organization to ensure that the activities follow the standard. Monitoring is not merely an evaluation but also the prevention of plausible deviations. It is in line with Kadarman, who asserts that monitoring is a systematic attempt to determine standard performance and planning to design an information feedback system, compare the actual performance to the standard, discover any deviations, and take corrective actions to achieve company objectives. Good monitoring will improve employee's job effectiveness (Zuliyati, 2005).

This result is reinforced by Pasaribu (2017), mentioning that monitoring positively and significantly affected employee's job effectiveness due to many benefits obtained by monitoring employees, institutions, and leaders. Therefore, before performing a monitoring action, a monitoring system suitable to the employee and institution's situation and condition should be prepared. Besides, a supervisor understanding the monitoring system should be assigned to execute the monitoring action well.

Monitoring benefits are applicable to many parties, including employees, leaders, and institutions. The benefit comprises increased job effectiveness. Monitoring enables employees to examine their job outcomes and boost their job 
effectiveness. Therefore, monitoring plays a role in improving employee's job effectiveness.

The Effect
communication of on $\begin{gathered}\text { Organizational } \\ \text { Employee's Job }\end{gathered}$

From the hypothesis $\mathrm{H} 2$ testing result, organizational communication positively and significantly affected the job effectiveness of BPJS KC Kuningan Office employees. Good organizational communication execution is a vital factor to improve employee's job effectiveness since organizational communication is the custom to regulate relationships among individuals and groups to generate great works. The study result shows that organizational communication was categorized as good, observed from the communication as coordination action, sharing information, and expressing emotions and feelings. In an organization, roles should be assigned to each member to operate into employee tasks and functions. In conducting such tasks and functions appropriately, effective communication is required to create unified cooperation among employees.

Such cooperation will be generated if supported by good communication because communication is a means to foster mutual concerns among individuals and create a joyful work atmosphere to actualize cooperation, respect, and acknowledgment of each member's existence. Ultimately, the working relationship within such an organization will be executed well, e.g., subordinates deliver opinions, suggestions, and proposals as expected by the superiors or leaders.

As revealed by Liliweri (2004) and (Faizal et al., 2019) "if we talk about organization as humans working together, then the keyword for organization effectiveness lies on communication effectiveness." It proves that organizational communication highly affects the achievement of organization objectives by improving employee's job effectiveness. Therefore, it is each element's obligation within an organization to perform their tasks and responsibilities perfectly. Simultaneously, good organizational communication will ensure the activities run as expected.

The study results follow a study by Mokodompi (2015) titled the effect of organizational communication on employee performance, revealing a significant relationship between organizational communication and employee performance in PT Memora Anoa Indah.

\section{Conclusion and Implication}

Many factors affect employee's job effectiveness, including monitoring and organizational communication. In this study, the author discovered that monitoring and organizational communication positively and significantly affect employee's job effectiveness. It is evident from the two proposed hypotheses, where they are accepted/supported. It indicates the importance of periodic monitoring of the activities. Also, communication between employees and leaders should be maintained to achieve the employee's job effectiveness.

\section{REFERENCES}

Bakhri, S., Nanik, R., \& Pariyanti, E. (2021). Meningkatkan Produktivitas Di Tempat Kerja: Sebuah Kajian Literatur Tentang Peranan Motivasi Kerja Dan Pengawasan. In PROSIDING SENANTIAS: Seminar Nasional Hasil Penelitian Dan Pengabdian Kepada Masyarakat (Vol. 1, No. 1, Pp. 89-96).

Devi, A. S. (2016). "Pengaruh Disiplin Dan Pengawasan Kerja Terhadap Efektivitas Kerja Pegawai Pada Kantor BRI Unit Sekip Medan.

Faizal, R., Sulaeman, M., \& Yulizar, I. (2019). Pengaruh Budaya, Motivasi Kerja Dan Kompetensi Terhadap Kinerja Karyawan. EBA Journal: Journal Economics, Bussines and Accounting, 5(1), 11-21. https://doi.org/10.32492/eba.v5i1.706 
Greenbaum, Sidney.2004. An Introduction

To English Grammar. Great Britain:

Pearson Education Limited

Ichsan, R. N. (2019). Kepemimpinan, Komunikasi Dan Efektivitas Kerja Pegawai Pemerintah Kota Lhokseumawe. JUMANT, 11(1), 1318.

Ilyas, Y., \& Saputro, T. N. (2020). Pengaruh Disiplin Kerja Dan Pengawasan Melekat Terhadap Efektivitas Kerja Pegawai Sekretariat Daerah Kabupaten Bogor. Economicus, 14(1), 25-34.

Kadarman, Yusuf Udaya. Edisi, Cet.5. No. Panggil, $658 \mathrm{Kad}$ P. ISBN/ISSN, 9796058340.

Katz, D., \& Kahn, R. L. (1978). The Social Psychology Of Organization (2nd. Ed.). New York : John Willey And Sons.

Kumorotomo, Wahyu. 1994. Sistem Informasi Manajemen Dalam Organisasiorganisasi Publik, Gadjah Mada University Press: Yogyakarta

Kusuma, A. M., Budiwibowo, S., \& Amah, N. (2017). Pengaruh Kepemimpinan Kepala Sekolah Dan Komunikasi Internal Terhadap Efektivitas Kerja Guru SMK PGRI Wonoasri. Assets: Jurnal Akuntansi Dan Pendidikan, 5(1), 41-52.

Liliweri, Alo. 2004. Wacana Komunikasi Kantor. Bandung: Mandar Maju.

Maulina, Nadia, 2014. Korelasi Pengawasan Dengan Efektivitas Kerja Pegawai Pada Kantor Kecamatan Samarinda Utara Kota Samarinda Ejournal Lmu Administrasi, 2 (1): 13-27

Melani, P. D., Warso, M. M., \& Haryono, A. T. (2016). Pengaruh Komunikasi Organisasi, Stres Kerja, Dan Motivasi Kerja Terhadap Efektivitas Kerja Karyawan Dengan Kepuasan Kerja Sebagai Variabel Intervening Pada PT Ungaran Sari Garments III Pringapus Unit Pringapus III Departemen Sewing Assembly Line. Journal Of Management, 2(2).

Mokodompit, F. R. (2013). Pengaruh Komunikasi Organisasi Terhadap
Efektivitas Kinerja Pada PT. Radio Memora Anoa Indah. ACTA DIURNA KOMUNIKASI, 2(2).

Noor, J. (2013). Penelitian Ilmu Manajemen: Tinjauan Filosofis Dan Praktis. Jakarta: Predana Media Group

Pace, Wayne \& Don Faules, "Komunikasi Organisasi. : Strategi Meningkatkan Kinerja Perusahaan", Bandung : PT. Remaja Rosdakarya, 2010

Pasaribu, Evan Karno Dan Indrawati, Ayu Desi. 2017. Pengaruh Iklim Organisasi Dan Kualitas Kehidupan Kerja Terhadap Kinerja Pegawai Dinas Sosial Provinsi Bali. E-Jurnal Manajemen UNUD, Volume 5, Nomor 12, 2016.

Rahayu, E. D. (2006). Pengaruh Disiplin Kerja Dan Pengawasan Kerja Terhadap Efektivitas Kerja Pegawai Pada Badan Kepegawaian Daerah Kota Semarang (Doctoral Dissertation, Universitas Negeri Semarang).

Rido, R., Umar, A., \& Nongkeng, H. (2019). Pengaruh Kepemimpinan, Disiplin Kerja, Dan Pengawasan Terhadap Efektivitas Kerja Pegawai Di Dinas Pengendalian Penduduk Dan Keluarga Berencana Kabupaten Bantaeng. YUME: Journal Of Management, 2(1).

Rustiana, A., \& Rosmawati, N. H. (2010). Pengaruh Tata Ruang Dan Komunikasi Intern Terhadap Efektivitas Kerja Guru Di Smk Negeri 9 Semarang. Dinamika Pendidikan, 5(1).

Sedarmayanti, M.Pd,. APU. 2009, Sumber Daya Manusia Dan Produktivitas Kerja. Bandung : Penerbit Mandar Maju.

Siagian, S. P. (2003). Teori Dan Praktek Kepemimpinan (Cetakan Kelima). Jakarta: Rineka Cipta.

Siagian, Sondang. 2015. Manajemen Sumber Daya Manusia, Jakarta:Bumi Aksara.

Simamora, F. N. (2018). Pengaruh Komunikasi Dan Kemampuan Sumber Daya Manusia Terhadap Efektivitas Kerja Pegawai Kantor Camat Sibolga Sambas Kota Sibolga. Warta Dharmawangsa, (55). 
Sirait Justine T., 2014, Memahami Aspek Pengelolaan SDM Dalam Organisasi, Jakarta: Grasinso.Steers (2015

Subekhan, M. (2017). Pengaruh Komunikasi Organisasi, Pengawasan Dan Kompetensi Terhadap Efektivitas Kerja Karyawan Unit Engineering Pt. Pura Barutama Kudus (Doctoral Dissertation, UMK).

Sudrajat, D. (2020). Dampak Pengawasan Terhadap Efektivitas Kerja Pegawai Kecamatan Cipedes Kota Tasikmalaya. Jak Publik (Jurnal Administrasi \& Kebijakan Publik), 1(3).

Sugiyono. (2017). Metode Penelitian Kuantitatif, Kualitatif, Dan R\&D. Bandung : Alfabeta, CV. Sugiyono. (2016). Metode Penelitian Kuantitatif, Kualitatif Dan R\&D. Bandung: PT Alfabet

Bangun, Wilson. 2012. "Manajemen Sumber Daya Manusia". Jakarta: Erlangga.

Zuliyati. N. Arya. 2011. Intellectual Capital Dan Kinerja Keuangan Perusahaan. Dinamika Keuangan Perbankan Vol 3 No. 1: 113-125 